\title{
Solvent and Temperature Effect on Chiral Conformation of Poly(meta-benzamide)s
}

\author{
Kanami Yamazaki, Akihiro Yokoyama, and Tsutomu Yokozawa*
}

\section{Supporting Information}

General. $\quad{ }^{1} \mathrm{H}$ and ${ }^{13} \mathrm{C}$ NMR spectra were obtained on JEOL ECA-500 and ECA-600 spectrometers, and the internal standards of ${ }^{1} \mathrm{H}$ and ${ }^{13} \mathrm{C}$ NMR spectra were tetramethylsilane $(0.00 \mathrm{ppm})$ and midpoint of $\mathrm{CDCl}_{3}(77.0 \mathrm{ppm})$, respectively. IR spectra were recorded on a JASCO FT/IR-410. Column chromatography was performed on silica gel (Kieselgel 60, 230-400 mesh, Merck) with a specified solvent. Commercially available (Kanto) dehydrated tetrahydrofuran (THF, stabilizer-free) was used as a dry solvent. The $M_{\mathrm{n}}$ and $M_{\mathrm{w}} / M_{\mathrm{n}}$ values of polymers were measured on a Shodex GPC-101 equipped with Shodex UV-41, Shodex RI-71S, and two Shodex KF-804L columns (bead size $=7 \mu \mathrm{m}$, pore size $=200 \AA$ ). THF was used as the eluent (temperature $=40{ }^{\circ} \mathrm{C}$, flow rate $=2 \mathrm{~mL} / \mathrm{min}$ ). Calibration was carried out using polystyrene standards. Isolation of polyamides was carried out with a Japan Analytical Industry LC-908 Recycling Preparative HPLC (eluent: chloroform) using two TSK-gel

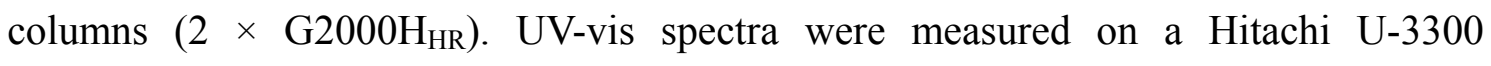
spectrophotometer and a JASCO V-550 spectrometer. CD spectra were measured on JASCO J-600 and J-820 spectropolarimeters using a $10 \mathrm{~mm}$ quartz cell. The concentration of each solution for UV and CD experiments was adjusted so that the absorbance of the monomers or the polymers was 1 at $250 \mathrm{~nm}$ for 1-4 and poly1-4 in chloroform and water, and for 3, 4, poly3, and poly4 in methanol, or at $260 \mathrm{~nm}$ for $\mathbf{1 , 2}$, poly 1 , and poly $\mathbf{2}$ in methanol. 
Synthesis of monomer 1. The monomer 1 was synthesized by the procedure as shown in Scheme S1.

\section{Scheme S1}

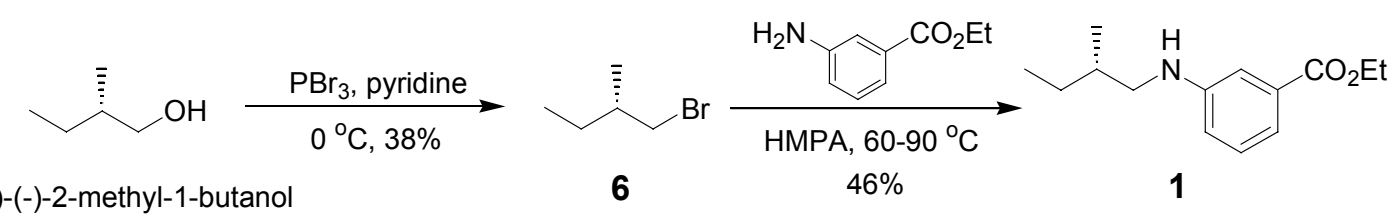

Synthesis of 6. ${ }^{1} \mathrm{PBr}_{3}(1.94 \mathrm{~mL}, 20.4 \mathrm{mmol})$ was added dropwise to a mixture of $(S)$-(-)-2-methyl-1-butanol $(5.01 \mathrm{~g}, 56.8 \mathrm{mmol})$ and pyridine $(1.5 \mathrm{~mL}, 18 \mathrm{mmol})$ at $0{ }^{\circ} \mathrm{C}$, and the whole was stirred at $0{ }^{\circ} \mathrm{C}$ for $2 \mathrm{~h}$ under an $\mathrm{Ar}$ atmosphere. Distillation $\left(80{ }^{\circ} \mathrm{C} / 10\right.$ $\mathrm{mmHg}$ ) of the reaction mixture gave a crude product as a distillate, which was diluted with $n$-pentane. The solution was washed with $5 \% \mathrm{NaOH}, 10 \% \mathrm{H}_{2} \mathrm{SO}_{4}$, and water, and dried over $\mathrm{CaCl}_{2}$. After removal of pentane at atmospheric pressure, the residue was distilled to give 6 as a colorless oil (2.95 g, 38\%): bp $118-120{ }^{\circ} \mathrm{C}\left(\right.$ lit. $\left.^{2} 118-120{ }^{\circ} \mathrm{C}\right) ;{ }^{1} \mathrm{H}$ NMR (500 MHz, $\left.\mathrm{CDCl}_{3}\right) \delta 3.40(\mathrm{dd}, J=9.9$ and $5.0 \mathrm{~Hz}, 1 \mathrm{H}), 3.33(\mathrm{dd}, J=9.7$ and 6.3 $\mathrm{Hz}, 1 \mathrm{H}), 1.72$ (oct, $J=6.0 \mathrm{~Hz}, 1 \mathrm{H}), 1.54-1.45$ (m, $1 \mathrm{H}), 1.32-1.24(\mathrm{~m}, 1 \mathrm{H}), 1.01$ (d, $J$ $=6.9 \mathrm{~Hz}, 3 \mathrm{H}), 0.91(\mathrm{t}, J=7.6 \mathrm{~Hz}, 3 \mathrm{H})$.

Synthesis of 1. Ethyl 3-aminobenzoate $(3.0 \mathrm{~mL}, 20 \mathrm{mmol})$ was added to a solution of $6(2.01 \mathrm{~g}, 13.3 \mathrm{mmol})$ in hexamethylphosphoric triamide (HMPA, $10 \mathrm{~mL}$ ). The mixture was stirred under an Ar atmosphere at $60{ }^{\circ} \mathrm{C}$ for $2 \mathrm{~h}$ and then at $90{ }^{\circ} \mathrm{C}$ for $22 \mathrm{~h}$, and poured into saturated aqueous $\mathrm{NaHCO}_{3}$. The mixture was extracted with ether, and the organic layer was washed with water and brine, dried over $\mathrm{MgSO}_{4}$, and evaporated. The residue was purified by silica gel column chromatography $(\mathrm{AcOEt} / \mathrm{hexane}=1 / 10)$ to give 1 as a yellow viscous oil $(1.45 \mathrm{~g}, 46 \%):{ }^{1} \mathrm{H}$ NMR $\left(600 \mathrm{MHz}, \mathrm{CDCl}_{3}\right) \delta 7.34(\mathrm{~d}, J$ $=7.6 \mathrm{~Hz}, 1 \mathrm{H}), 7.26(\mathrm{~m}, 1 \mathrm{H}), 7.21(\mathrm{t}, J=7.9 \mathrm{~Hz}, 1 \mathrm{H}), 6.76(\mathrm{dd}, J=8.1$ and $2.5 \mathrm{~Hz}, 1$ H), 4.35 (q, $J=7.2 \mathrm{~Hz}, 2 \mathrm{H}), 3.80($ br s, $1 \mathrm{H}), 3.09$ (dd, $J=12.4$ and $6.2 \mathrm{~Hz}, 1 \mathrm{H}), 2.93$ (dd, $J=12.3$ and $7.2 \mathrm{~Hz}, 1 \mathrm{H}), 1.67$ (oct, $J=6.5 \mathrm{~Hz}, 1 \mathrm{H}$ ), 1.53-1.47 (m, $1 \mathrm{H}$ ), 1.38 (t, $J$ $=7.2 \mathrm{~Hz}, 3 \mathrm{H}), 1.27-1.20(\mathrm{~m}, 1 \mathrm{H}), 0.98(\mathrm{~d}, J=6.9 \mathrm{~Hz}, 3 \mathrm{H}), 0.94(\mathrm{t}, J=7.6 \mathrm{~Hz}, 3 \mathrm{H})$;

${ }^{13} \mathrm{C}$ NMR $\left(126 \mathrm{MHz}, \mathrm{CDCl}_{3}\right) \delta 160.1,141.6,124.3,122.0,111.0,109.8,106.2,53.8$, 42.8, 27.4, 20.2, 10.5, 7.3, 4.3; IR (neat) 2961, 2930, 2874, 1606, 1514, 1490, 1474, $1367,1334,753,684 \mathrm{~cm}^{-1}$. 
Synthesis of monomer 2. The monomer 2 was synthesized by the procedure as shown in Scheme $\mathrm{S} 2$.

\section{Scheme S2}

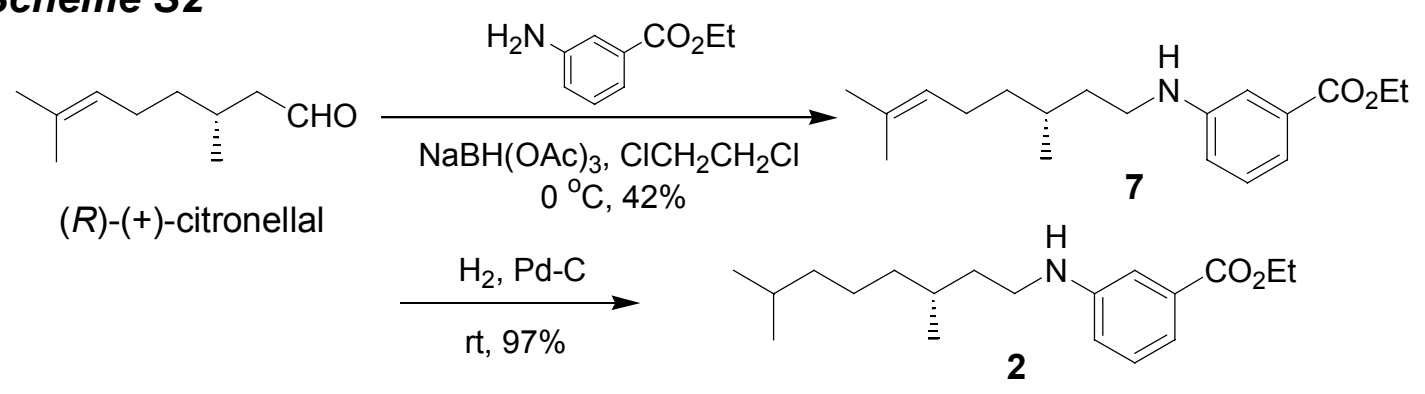

Synthesis of $7 .^{3} \mathrm{NaBH}(\mathrm{OAc})_{3}(3.22 \mathrm{~g}, 15.2 \mathrm{mmol})$ was added to a solution of $(R)-(+)$-citronellal $(2.00 \mathrm{~g}, 13.0 \mathrm{mmol})$ and ethyl 3-aminobenzoate $(2.0 \mathrm{~mL}, 13 \mathrm{mmol})$ in 1,2-dichloroethane $(45 \mathrm{~mL})$ at $0{ }^{\circ} \mathrm{C}$. After stirred at $0{ }^{\circ} \mathrm{C}$ for $3 \mathrm{~h}$ under an $\mathrm{Ar}$ atmosphere, the reaction mixture was neutralized with saturated $\mathrm{NaHCO}_{3}$ and extracted with AcOEt. The organic layer was washed with water and brine, dried over $\mathrm{MgSO}_{4}$, and evaporated. The residue was purified by silica gel column chromatography $($ AcOEt/hexane $=1 / 10)$ to give 7 as a pale yellow oil $(1.66 \mathrm{~g}, 42 \%):{ }^{1} \mathrm{H} \mathrm{NMR}(600 \mathrm{MHz}$, $\left.\mathrm{CDCl}_{3}\right) \delta 7.35(\mathrm{dt}, J=7.7$ and $1.2 \mathrm{~Hz}, 1 \mathrm{H}), 7.26(\mathrm{~m}, 1 \mathrm{H}), 7.21(\mathrm{t}, J=7.9 \mathrm{~Hz}, 1 \mathrm{H})$, $6.76(\mathrm{ddd}, J=8.0,2.6$, and $1.0 \mathrm{~Hz}, 1 \mathrm{H}), 5.10(\mathrm{t}, J=7.2 \mathrm{~Hz}, 1 \mathrm{H}), 4.35(\mathrm{q}, J=7.2 \mathrm{~Hz}, 2$ H), 3.68 (br s, $1 \mathrm{H}), 3.20-3.11(\mathrm{~m}, 2 \mathrm{H}), 2.02-1.95$ (m, $2 \mathrm{H}), 1.69-1.56(\mathrm{~m}, 10 \mathrm{H})$, $1.48-1.35(\mathrm{~m}, 5 \mathrm{H}), 1.25-1.19(\mathrm{~m}, 1 \mathrm{H}), 0.95(\mathrm{~d}, J=6.5 \mathrm{~Hz}, 3 \mathrm{H}) ;{ }^{13} \mathrm{C}$ NMR $(126 \mathrm{~Hz}$, $\left.\mathrm{CDCl}_{3}\right) \delta 167.1,148.5,131.4,129.1,124.6,118.2,117.0,113.3,60.8,41.9,37.1,36.6$, 30.4, 25.7, 25.5, 19.6, 17.7, 14.4; IR (neat) 2966, 2926, 1670, 1609, 1366, 1333, 1239, $1105,752,685 \mathrm{~cm}^{-1}$.

Synthesis of 2. A catalytic amount of $5 \% \mathrm{Pd}-\mathrm{C}(0.35 \mathrm{~g})$ was added to a solution of 7 $(1.30 \mathrm{~g}, 4.29 \mathrm{mmol})$ in AcOEt $(200 \mathrm{~mL})$, and hydrogenation was carried out at room temperature for $3 \mathrm{~h}$ under a $\mathrm{H}_{2}$ atmosphere with vigorous stirring. The reaction mixture was filtered and evaporated, and the residue was purified by silica gel column chromatography $(\mathrm{AcOEt} /$ hexane $=1 / 10)$ to give 2 as a pale yellow viscous oil $(1.27 \mathrm{~g}$, 97\%). ${ }^{1} \mathrm{H}$ NMR (600 MHz, $\left.\mathrm{CDCl}_{3}\right) \delta 7.35(\mathrm{dt}, J=7.9$ and $1.2 \mathrm{~Hz}, 1 \mathrm{H}), 7.26(\mathrm{~m}, 1 \mathrm{H})$, $7.21(\mathrm{t}, J=7.9 \mathrm{~Hz}, 1 \mathrm{H}), 6.76(\mathrm{ddd}, J=7.9,2.4$, and $1.0 \mathrm{~Hz}, 1 \mathrm{H}), 4.35(\mathrm{q}, J=7.2 \mathrm{~Hz}, 2$ H), 3.67 (br s, 1 H), 3.20-3.10 (m, $2 \mathrm{H}), 1.67-1.62(\mathrm{~m}, 1 \mathrm{H}), 1.57-1.51$ (m, $2 \mathrm{H})$, 1.49-1.41 (m, $1 \mathrm{H}), 1.39-1.23(\mathrm{~m}, 6 \mathrm{H}), 1.18-1.12(\mathrm{~m}, 3 \mathrm{H}), 0.94(\mathrm{~d}, J=6.9 \mathrm{~Hz}, 3 \mathrm{H})$, $0.87(\mathrm{~d}, J=6.9 \mathrm{~Hz}, 6 \mathrm{H}) ;{ }^{13} \mathrm{C}$ NMR $\left(126 \mathrm{MHz}, \mathrm{CDCl}_{3}\right) \delta 167.1,148.5,131.4,129.0$, 
$118.2,117.0,113.3,60.8,41.9,39.2,37.2,36.7,30.8,28.0,24.7,22.7,22.6,19.7,14.3$; IR (neat) 2955, 2926, 2869, 1707, 1366, 1334, 1240, 1106, 752, $684 \mathrm{~cm}^{-1}$.

Synthesis of monomer 3 . The monomer $\mathbf{3}$ was synthesized by the procedure as shown in Scheme S3.

\section{Scheme S3}

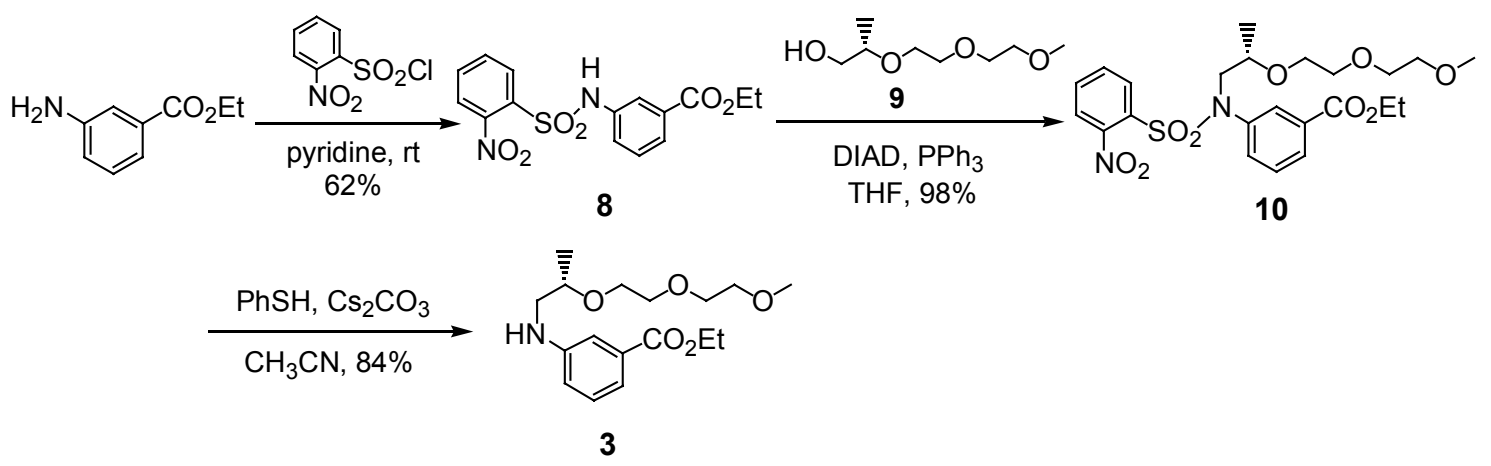

Synthesis of 8. To a solution of ethyl 3-aminobenzoate $(4.72 \mathrm{~g}, 28.6 \mathrm{mmol})$ in pyridine $(30 \mathrm{~mL})$ was added 2-nitrobenzenesulfonyl chloride $(7.00 \mathrm{~g}, 31.6 \mathrm{mmol})$ at 0 ${ }^{\circ} \mathrm{C}$. The mixture was stirred at room temperature for $2.5 \mathrm{~h}$, and poured into $2 \mathrm{M} \mathrm{HCl}$ (135 mL). The aqueous layer was extracted with $\mathrm{CH}_{2} \mathrm{Cl}_{2}$ and the organic layer was washed with brine, dried over $\mathrm{MgSO}_{4}$, and evaporated. The residue was purified by silica gel column chromatography (AcOEt/hexane $=1 / 1)$ to give 8 as a light brown solid (6.19 g, 62\%): ${ }^{1} \mathrm{H}$ NMR (500 MHz, $\left.\mathrm{CDCl}_{3}\right) \delta 7.89-7.85$ (m, $\left.3 \mathrm{H}\right), 7.80$ (t, $J=1.9 \mathrm{~Hz}, 1$ $\mathrm{H}), 7.71(\mathrm{td}, J=7.7$ and $1.4 \mathrm{~Hz}, 1 \mathrm{H}), 7.60(\mathrm{td}, J=7.7$ and $1.4 \mathrm{~Hz}, 1 \mathrm{H}), 7.48(\mathrm{ddd}, J=$ 8.0, 2.3, and $1.1 \mathrm{~Hz}, 1 \mathrm{H}), 7.42(\mathrm{br} \mathrm{s}, 1 \mathrm{H}), 7.38(\mathrm{t}, J=7.9 \mathrm{~Hz}, 1 \mathrm{H}), 4.36$ (q, $J=7.1 \mathrm{~Hz}$, $2 \mathrm{H}), 1.37(\mathrm{t}, J=7.3 \mathrm{~Hz}, 3 \mathrm{H}) ;{ }^{13} \mathrm{C} \mathrm{NMR}\left(126 \mathrm{MHz}, \mathrm{CDCl}_{3}\right) \delta 165.6,135.8,134.1$, 132.7, 132.1, 131.9, 131.7, 129.6, 127.5, 127.3, 125.5, 123.8, 61.4, 14.2; IR (KBr) 3084, $1592,1537,1420,1360,782,752 \mathrm{~cm}^{-1}$.

Synthesis of 10. Diisopropyl azodicarboxylate (DIAD, $40 \%$ in toluene, $3.8 \mathrm{~mL}, 7.1$ mmol) was added to a solution of $8(1.91 \mathrm{~g}, 5.46 \mathrm{mmol}), \mathbf{9}^{4}(0.667 \mathrm{~g}, 3.74 \mathrm{mmol})$, and $\mathrm{PPh}_{3}(1.65 \mathrm{~g}, 6.29 \mathrm{mmol})$ in dry THF $(20 \mathrm{~mL})$ at $0{ }^{\circ} \mathrm{C}$ under an Ar atmosphere. The mixture was stirred at room temperature for $13 \mathrm{~h}$, and concentrated under reduced pressure. The residue was purified by silica gel column chromatography (AcOEt/hexane $=1 / 1)$ to give 10 as a yellow viscous oil $(1.87 \mathrm{~g}, 98 \%):{ }^{1} \mathrm{H}$ NMR $\left(500 \mathrm{MHz}, \mathrm{CDCl}_{3}\right) \delta$ 
$7.97(\mathrm{dt}, J=7.7$ and $1.4 \mathrm{~Hz}, 1 \mathrm{H}), 7.83(\mathrm{t}, J=1.9 \mathrm{~Hz}, 1 \mathrm{H}), 7.64(\mathrm{td}, J=7.6$ and $1.4 \mathrm{~Hz}$, $1 \mathrm{H}), 7.60(\mathrm{dd}, J=8.0$ and $1.4 \mathrm{~Hz}, 1 \mathrm{H}), 7.55(\mathrm{ddd}, J=8.0,2.3$, and $1.1 \mathrm{~Hz}, 1 \mathrm{H}), 7.51$ $(\mathrm{dd}, J=7.9$ and $1.4 \mathrm{~Hz}, 1 \mathrm{H}), 7.46(\mathrm{td}, J=7.0$ and $1.4 \mathrm{~Hz}, 1 \mathrm{H}), 7.40(\mathrm{t}, J=7.9 \mathrm{~Hz}, 1 \mathrm{H})$, $4.35(\mathrm{q}, J=7.2 \mathrm{~Hz}, 2 \mathrm{H}), 3.86$ and $3.82(\mathrm{ABq}, J=14.5 \mathrm{~Hz}$, each part d with $J=6.7$ and $5.0 \mathrm{~Hz}, 2 \mathrm{H}), 3.64-3.50$ (m, $4 \mathrm{H}), 3.50-3.45$ (m, $4 \mathrm{H}), 3.43-3.40$ (m, $1 \mathrm{H}), 3.36(\mathrm{~s}, 3 \mathrm{H})$, 1.37 (t, $J=7.2 \mathrm{~Hz}, 3 \mathrm{H}), 1.20(\mathrm{~d}, J=6.0 \mathrm{~Hz}, 3 \mathrm{H}) ;{ }^{13} \mathrm{C} \mathrm{NMR}\left(126 \mathrm{MHz}, \mathrm{CDCl}_{3}\right) \delta 165.5$, 139.5 , 134.2, 133.7, 131.9, 131.8, 131.1, 129.9, 129.2, 123.9, 74.7, 71.9, 70.5, 68.1, $61.3,57.0$; IR (neat) 2979, 2877, 1586, 1546, 1369, 1108, 765, $695 \mathrm{~cm}^{-1}$.

Synthesis of 3 . A solution of benzenethiol $(0.380 \mathrm{~g}, 3.45 \mathrm{mmol})$ in $\mathrm{CH}_{3} \mathrm{CN}(10 \mathrm{~mL})$ and $\mathrm{Cs}_{2} \mathrm{CO}_{3}(3.16 \mathrm{~g}, 9.68 \mathrm{mmol})$ were added to a solution of 10 (1.68 g, $\left.3.30 \mathrm{mmol}\right)$ in $\mathrm{CH}_{3} \mathrm{CN}(70 \mathrm{~mL})$. The reaction mixture was stirred at $80{ }^{\circ} \mathrm{C}$ for $1.5 \mathrm{~h}$, allowed to cool to room temperature, and poured into water. The mixture was extracted with $\mathrm{CH}_{2} \mathrm{Cl}_{2}$. The organic layer was washed with water, dried over $\mathrm{MgSO}_{4}$, and evaporated. The residue was purified by silica gel column chromatography $(\mathrm{AcOEt} / \mathrm{hexane}=2 / 1$, then $1 / 1)$ to give 3 as a yellow oil $(0.904 \mathrm{~g}, 84 \%)$ : ${ }^{1} \mathrm{H}$ NMR (500 $\left.\mathrm{MHz}, \mathrm{CDCl}_{3}\right) \delta 7.36(\mathrm{dt}, J=7.5$ and $1.3 \mathrm{~Hz}, 1 \mathrm{H}), 7.26(\mathrm{t}, J=2.0 \mathrm{~Hz}, 1 \mathrm{H}), 7.21(\mathrm{t}, J=7.9 \mathrm{~Hz}, 1 \mathrm{H}), 6.81(\mathrm{ddd}, J=8.1$, 2.5, and $1.1 \mathrm{~Hz}, 1 \mathrm{H}), 4.47(\mathrm{br} \mathrm{s}, 1 \mathrm{H}), 4.35(\mathrm{q}, J=7.2 \mathrm{~Hz}, 2 \mathrm{H}), 3.78-3.72(\mathrm{~m}, 2 \mathrm{H})$, 3.68-3.62 (m, $4 \mathrm{H}), 3.60-3.53(\mathrm{~m}, 3 \mathrm{H}), 3.39$ (s, $3 \mathrm{H}), 3.27(\mathrm{dd}, J=12.7$ and $3.2 \mathrm{~Hz}, 1$ $\mathrm{H}), 3.07(\mathrm{dd}, J=12.6$ and $7.7 \mathrm{~Hz}, 1 \mathrm{H}), 1.38(\mathrm{t}, J=7.2 \mathrm{~Hz}, 3 \mathrm{H}), 1.24(\mathrm{~d}, J=6.3 \mathrm{~Hz}, 3$ $\mathrm{H}) ;{ }^{13} \mathrm{C} \mathrm{NMR}\left(126 \mathrm{MHz}, \mathrm{CDCl}_{3}\right) \delta 167.1,148.5,131.2,129.0,118.3,74.2,71.9,70.7$, 70.5, 67.9, 60.7, 59.0, 49.0, 17.8, 14.3; IR (neat) 2978, 2932, 2874, 2368, 1606, 1105, $754 \mathrm{~cm}^{-1}$.

Synthesis of monomer 4 . The monomer 4 was synthesized by the procedure as shown in Scheme S4.

Synthesis of 11. $\mathrm{NaOH}(3.86 \mathrm{~g}, 96.4 \mathrm{mmol})$ and triethylene glycol monomethyl ether $(12.4 \mathrm{~g}, 75.6 \mathrm{mmol})$ in a mixture of water $(40 \mathrm{~mL})$ and THF $(45 \mathrm{~mL})$ was stirred at $0{ }^{\circ} \mathrm{C}$. $p$-Toluenesulfonyl chloride $(12.0 \mathrm{~g}, 63.0 \mathrm{mmol})$ in THF $(45 \mathrm{~mL})$ was added dropwise to the mixture. The solution was stirred at $0{ }^{\circ} \mathrm{C}$ for $1.5 \mathrm{~h}$, then poured into ice-water, and the mixture was extracted with $\mathrm{CH}_{2} \mathrm{Cl}_{2}$. The organic layer was washed with brine, dried over $\mathrm{MgSO}_{4}$ and evaporated, and the residue was purified by silica gel column chromatography $(\mathrm{AcOEt} / \mathrm{hexane}=2: 1)$ to give $\mathbf{1 1}$ as a colorless oil (14.6 g, 


\section{Scheme S4}

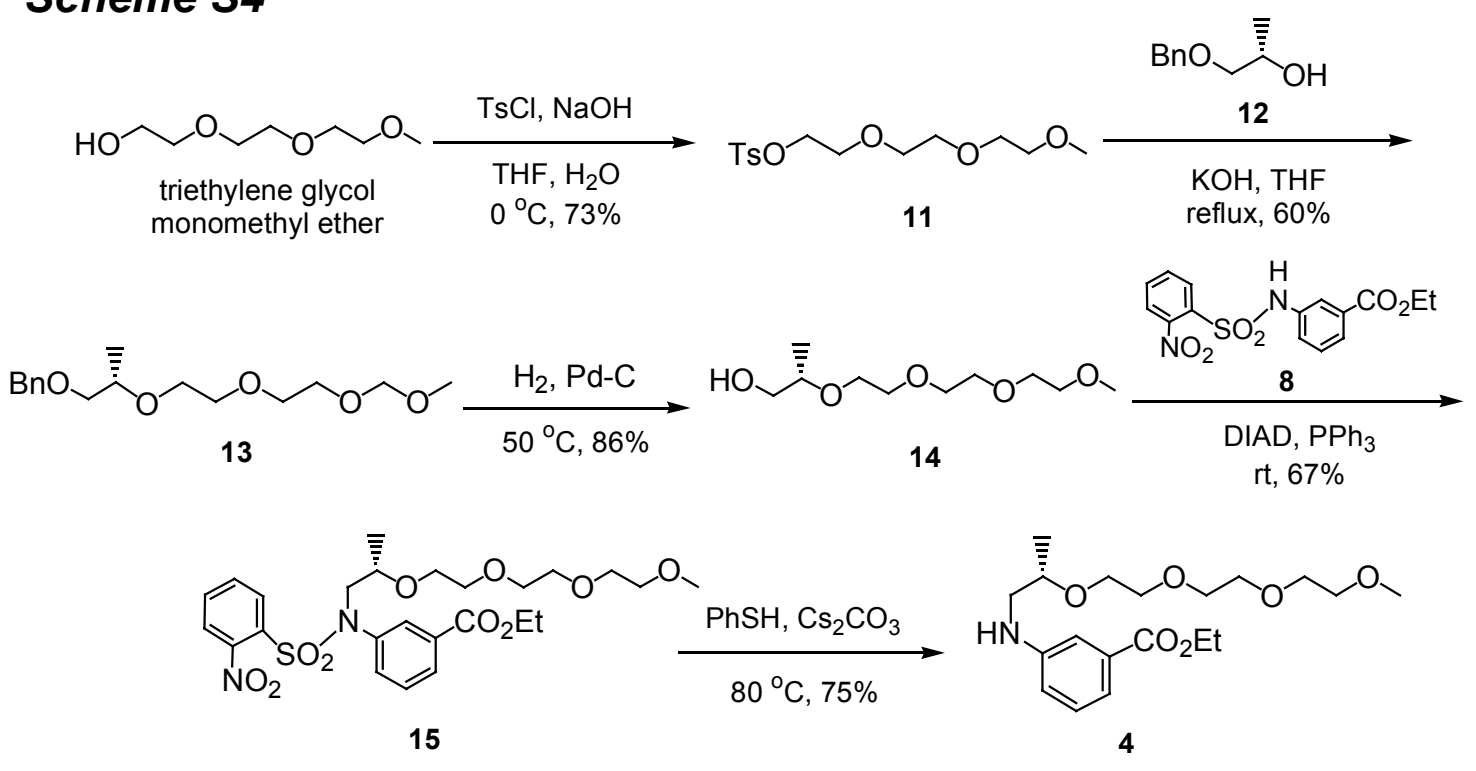

73\%): ${ }^{1} \mathrm{H}$ NMR (500 MHz, $\left.\mathrm{CDCl}_{3}\right) \delta 7.80(\mathrm{~d}, J=8.3 \mathrm{~Hz}, 2 \mathrm{H}), 7.34(\mathrm{~d}, J=8.0 \mathrm{~Hz}, 2 \mathrm{H})$, $4.16(\mathrm{t}, J=4.9 \mathrm{~Hz}, 2 \mathrm{H}), 3.69(\mathrm{t}, J=4.9 \mathrm{~Hz}, 2 \mathrm{H}), 3.62-3.58(\mathrm{~m}, 6 \mathrm{H}), 3.53(\mathrm{dd}, J=6.3$ and $3.2 \mathrm{~Hz}, 2 \mathrm{H}), 3.37(\mathrm{~s}, 3 \mathrm{H}), 2.45(\mathrm{~s}, 3 \mathrm{H}) ;{ }^{13} \mathrm{C} \mathrm{NMR}\left(126 \mathrm{MHz}, \mathrm{CDCl}_{3}\right) \delta 144.8$, 133.0, 129.8, 127.9, 71.9, 70.7, 70.51, 70.50, 69.2, 68.6, 59.0, 21.6; IR (neat) 2925, $2879,1356,1177,818 \mathrm{~cm}^{-1}$.

Synthesis of 13. A solution of $\mathbf{1 2}^{4}(6.01 \mathrm{~g}, 36.1 \mathrm{mmol}), \mathbf{1 1}(23.0 \mathrm{~g}, 72.4 \mathrm{mmol})$ and $\mathrm{KOH}(6.91 \mathrm{~g}, 123 \mathrm{mmol})$ in dry THF $(95 \mathrm{~mL})$ was stirred under reflux for $17 \mathrm{~h}$ under an Ar atmosphere, allowed to cool to room temperature, and poured into water. The mixture was extracted with $\mathrm{CH}_{2} \mathrm{Cl}_{2}$. The organic layer was washed with water, dried over $\mathrm{MgSO}_{4}$, and evaporated. The residue was purified by distillation (135.0-150.5 ${ }^{\circ} \mathrm{C} / 0.18 \mathrm{mmHg}$ ) followed by silica gel column chromatography $(\mathrm{AcOEt} / \mathrm{hexane}=1 / 1)$ to give 13 as a pale yellow oil $(6.96 \mathrm{~g}, 60 \%):{ }^{1} \mathrm{H} \mathrm{NMR}\left(500 \mathrm{MHz}, \mathrm{CDCl}_{3}\right) \delta 7.36-7.27$ $(\mathrm{m}, 5 \mathrm{H}), 4.57(\mathrm{~d}, J=4.6 \mathrm{~Hz}, 2 \mathrm{H}), 3.71-3.62(\mathrm{~m}, 11 \mathrm{H}), 3.56-3.53(\mathrm{~m}, 1 \mathrm{H}), 3.51(\mathrm{dd}, J$ $=10.0$ and $6.0 \mathrm{~Hz}, 1 \mathrm{H}), 3.41(\mathrm{dd}, J=10.0$ and $6.0 \mathrm{~Hz}, 1 \mathrm{H}), 3.37(\mathrm{~s}, 3 \mathrm{H}), 1.17(\mathrm{~d}, J=$ $6.3 \mathrm{~Hz}, 3 \mathrm{H}) ;{ }^{13} \mathrm{C} \mathrm{NMR}\left(126 \mathrm{MHz}, \mathrm{CDCl}_{3}\right) \delta 138.4,128.3,127.6,127.5,75.0,74.0$, $73.2,71.9,70.8,70.6,70.52,70.45,68.5,59.0,17.2$; IR (neat) 2979, 2925, 2865, 1638, $1373,741,704 \mathrm{~cm}^{-1}$.

Synthesis of 14. The benzyl ether 13 (1.22 g, $3.89 \mathrm{mmol})$ was dissolved in ethanol $(13 \mathrm{~mL})$ and acidified with $37 \% \mathrm{HCl}(0.1 \mathrm{~mL})$. A catalytic amount of $5 \% \mathrm{Pd} / \mathrm{C}(0.157 \mathrm{~g})$ was added to the solution, and hydrogenation was carried out under a $\mathrm{H}_{2}$ atmosphere 
with vigorous stirring at $50{ }^{\circ} \mathrm{C}$ for $1 \mathrm{~h}$. The reaction mixture was filtered and evaporated, and the residue was purified by silica gel column chromatography (AcOEt) to give $\mathbf{1 4}$ as a pale yellow oil $(0.751 \mathrm{~g}, 86 \%):{ }^{1} \mathrm{H} \mathrm{NMR}\left(500 \mathrm{MHz}, \mathrm{CDCl}_{3}\right) \delta 3.79-3.76(\mathrm{~m}, 1 \mathrm{H})$, 3.69-3.55 (m, $14 \mathrm{H}), 3.46(\mathrm{dd}, J=11.6$ and $7.5 \mathrm{~Hz}, 1 \mathrm{H}), 3.39(\mathrm{~s}, 3 \mathrm{H}), 1.11(\mathrm{~d}, J=6.3$ $\mathrm{Hz}, 3 \mathrm{H}) ;{ }^{13} \mathrm{C} \mathrm{NMR}\left(126 \mathrm{MHz}, \mathrm{CDCl}_{3}\right) \delta 71.8,70.8,70.39,70.38,70.3,67.9,66.2,58.9$, 16.0; IR (neat) 3435, 2930, 2887, 1646, $1093 \mathrm{~cm}^{-1}$.

Synthesis of 15. Coupling reaction between 14 and 8 was carried out in the same manner as the synthesis of 10. Purification by silica gel column chromatography $\left(\mathrm{AcOEt} /\right.$ hexane $=3 / 1$, and then $\left.\mathrm{CH}_{2} \mathrm{Cl}_{2} / \mathrm{AcOEt}=1 / 1\right)$ gave $\mathbf{1 5}$ as a viscous light brown oil (67\%): ${ }^{1} \mathrm{H}$ NMR (500 MHz, $\left.\mathrm{CDCl}_{3}\right) \delta 7.97(\mathrm{dt}, J=7.7$ and $1.3 \mathrm{~Hz}, 1 \mathrm{H}), 7.83(\mathrm{t}, J=$ $1.9 \mathrm{~Hz}, 1 \mathrm{H}), 7.64(\mathrm{td}, J=7.6$ and $1.4 \mathrm{~Hz}, 1 \mathrm{H}), 7.60(\mathrm{dd}, J=8.0$ and $1.7 \mathrm{~Hz}, 1 \mathrm{H}), 7.55$ (ddd, $J=7.8,2.2$, and $1.1 \mathrm{~Hz}, 1 \mathrm{H}), 7.51(\mathrm{dd}, J=8.0$ and $1.4 \mathrm{~Hz}, 1 \mathrm{H}), 7.47$ (td, $J=7.5$ and $1.5 \mathrm{~Hz}, 1 \mathrm{H}), 7.41(\mathrm{t}, J=7.9 \mathrm{~Hz}, 1 \mathrm{H}), 4.35(\mathrm{q}, J=7.2 \mathrm{~Hz}, 2 \mathrm{H}), 3.86$ and 3.82 (ABq, $J=14.6 \mathrm{~Hz}$, each part d with $J=6.9$ and $5.2 \mathrm{~Hz}, 2 \mathrm{H}), 3.63-3.47(\mathrm{~m}, 12 \mathrm{H})$, 3.45-3.39 (m, $1 \mathrm{H}), 3.37$ (s, $3 \mathrm{H}), 1.37$ (t, $J=7.2 \mathrm{~Hz}, 3 \mathrm{H}), 1.19$ (d, $J=6.9 \mathrm{~Hz}, 3 \mathrm{H})$; ${ }^{13} \mathrm{C}$ NMR $\left(126 \mathrm{MHz}, \mathrm{CDCl}_{3}\right) \delta 165.4,148.0,139.5,134.2,133.7,131.84,131.75,131.1$, $129.9,129.3,129.2,74.7,71.9,70.53,70.49,70.45,68.1,61.3,59.0,57.0,17.3,14.2$; IR (neat) 2984, 2933, 1638, 1364, 1281, 1168, 768, $699 \mathrm{~cm}^{-1}$.

Synthesis of 4. The 2-nitrobenzenesulfonyl group of $\mathbf{1 5}$ was removed in the same manner as the preparation of $\mathbf{3}$. Purification by silica gel column chromatography (AcOEt/hexane $=3 / 1$ ) followed by preparative HPLC gave 4 as a yellow oil $(75 \%):{ }^{1} \mathrm{H}$ $\operatorname{NMR}\left(500 \mathrm{MHz}, \mathrm{CDCl}_{3}\right) \delta 7.36(\mathrm{dt}, J=7.8$ and $1.3 \mathrm{~Hz}, 1 \mathrm{H}), 7.27-7.26(\mathrm{~m}, 1 \mathrm{H}), 7.20$ $(\mathrm{t}, J=7.9 \mathrm{~Hz}, 1 \mathrm{H}), 6.80(\mathrm{ddd}, J=8.0,2.6$, and $0.9 \mathrm{~Hz}, 1 \mathrm{H}), 4.49$ (br s, $1 \mathrm{H}), 4.35$ (q, $J$ $=7.1 \mathrm{~Hz}, 2 \mathrm{H}), 3.77-3.72(\mathrm{~m}, 2 \mathrm{H}), 3.69-3.64(\mathrm{~m}, 8 \mathrm{H}), 3.59-3.50(\mathrm{~m}, 3 \mathrm{H}), 3.37$ (s, 3 $\mathrm{H}), 3.27(\mathrm{dd}, J=12.6$ and $3.2 \mathrm{~Hz}, 1 \mathrm{H}), 3.07(\mathrm{dd}, J=12.6$ and $7.7 \mathrm{~Hz}, 1 \mathrm{H}), 1.38(\mathrm{t}, J=$ $7.2 \mathrm{~Hz}, 3 \mathrm{H}), 1.24$ (d, $J=6.3 \mathrm{~Hz}, 3 \mathrm{H}) ;{ }^{13} \mathrm{C} \mathrm{NMR}\left(126 \mathrm{MHz}, \mathrm{CDCl}_{3}\right) \delta 167.1,148.5$, 131.3, 129.0, 118.3, 117.6, 113.3, 74.2, 71.9, 70.8, 70.6, 70.54, 70.50, 67.9, 60.7, 59.0, 49.0, 17.8, 14.3; IR (neat) 2976, 2873, 2246, 1715, 1105, $755 \mathrm{~cm}^{-1}$.

Synthesis of Poly1-4. Poly1-4 were synthesized by the procedure as shown in Scheme S5. All glass apparatuses were dried prior to use. Addition of reagents into the reaction flask was carried out via a syringe from the three-way stopcock with a stream of nitrogen. 


\section{Scheme S5}

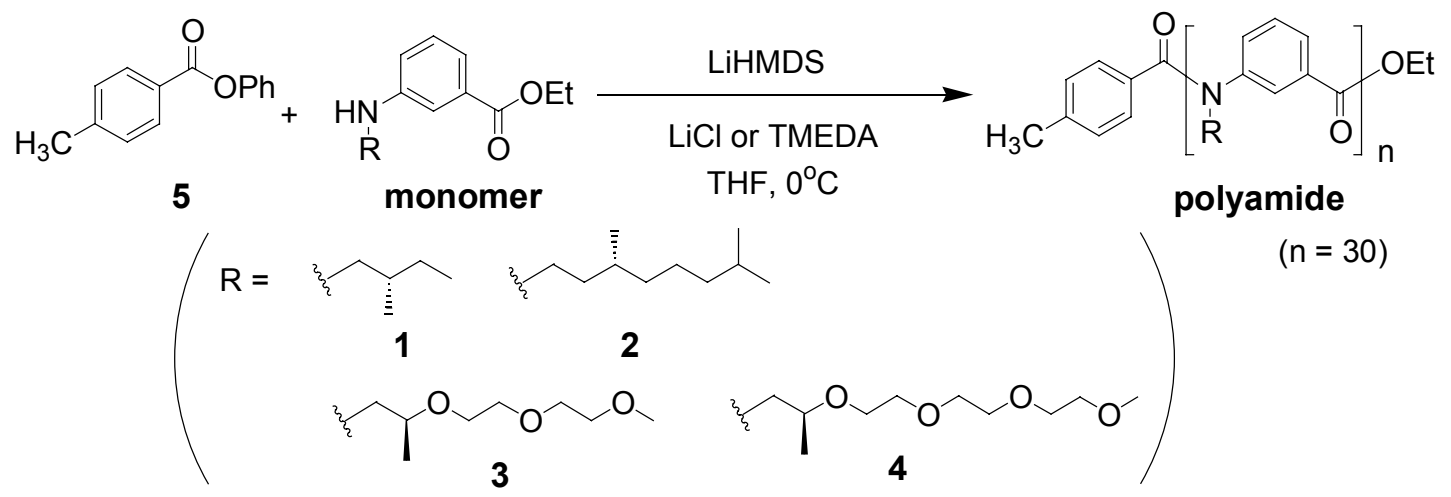

Synthesis of poly1. $\mathrm{LiCl}(0.119 \mathrm{~g}, 2.81 \mathrm{mmol})$ was placed in a flask equipped with a three-way stopcock, and dried at $250{ }^{\circ} \mathrm{C}$ under reduced pressure. The flask was cooled to room temperature under an Ar atmosphere, and then charged with dry THF $(0.60 \mathrm{~mL})$ and $1 \mathrm{M}$ solution of LiHMDS in THF $(0.60 \mathrm{~mL}, 0.60 \mathrm{mmol})$. The flask was cooled to 0 ${ }^{\circ} \mathrm{C}$ with stirring. Into the flask was added a solution of $5(0.0035 \mathrm{~g}, 0.017 \mathrm{mmol})$ in dry THF $(0.25 \mathrm{~mL})$, followed by a solution of $1(0.119 \mathrm{~g}, 0.504 \mathrm{mmol})$ in dry THF $(0.60$ $\mathrm{mL}$ ) dropwise over ca. $45 \mathrm{~min}$ (when reddish color of the reaction mixture disappeared, the next drop of the solution was added) at $0{ }^{\circ} \mathrm{C}$ with stirring. The reaction mixture was stirred at $0{ }^{\circ} \mathrm{C}$ for $1 \mathrm{~h}$, quenched with saturated $\mathrm{NH}_{4} \mathrm{Cl}$, and extracted with $\mathrm{CH}_{2} \mathrm{Cl}_{2}$. The organic layer was dried over $\mathrm{MgSO}_{4}$ and evaporated. The residue was purified by preparative HPLC (eluent: $\mathrm{CHCl}_{3}$ ) using polystyrene gel column to give poly1 as a off-white solid (90\%): ${ }^{1} \mathrm{H}$ NMR $\left(600 \mathrm{MHz}, \mathrm{CDCl}_{3}\right) \delta 7.11-7.03(\mathrm{~m}, 1 \mathrm{H}), 6.93-6.76(\mathrm{~m}$, $2 \mathrm{H}), 6.64$ (br s, $1 \mathrm{H}), 3.58$ (m, $2 \mathrm{H}), 1.50-1.41$ (m, $1 \mathrm{H}), 1.39-1.26$ (m, $1 \mathrm{H}), 1.15-1.07$ (m, $1 \mathrm{H}), 0.88-0.80$ (m, $6 \mathrm{H})$; IR (KBr) 2962, 2928, 2875, 1654, $748 \mathrm{~cm}^{-1}$.

Poly2. Pale yellow solid (68\%): ${ }^{1} \mathrm{H}$ NMR (500 MHz, $\left.\mathrm{CDCl}_{3}\right) \delta 7.17-7.05(\mathrm{~m}, 1 \mathrm{H})$, 6.86-6.71 (m, 2 H), 6.60 (br s, 1 H), 3.86-3.39 (m, 2 H), 1.53 (m, 1 H), 1.39-1.06 (m, 9 H), 0.90-0.83 (m, 9 H); IR (KBr) 2954, 2926, 2869, 1654, $749 \mathrm{~cm}^{-1}$.

Synthesis of poly3. A flask, equipped with a three-way stopcock, was purged with Ar and then charged with dry THF $(0.60 \mathrm{~mL}), 1 \mathrm{M}$ solution of LiHMDS in THF $(0.60$ $\mathrm{mL}, 0.60 \mathrm{mmol})$, and TMEDA $(0.35 \mathrm{~mL}, 2.3 \mathrm{mmol})$. The flask was cooled to $0{ }^{\circ} \mathrm{C}$ with stirring. Into the flask was added a solution of $5(0.0028 \mathrm{~g}, 0.013 \mathrm{mmol})$ in dry THF $(0.20 \mathrm{~mL})$, followed by a solution of $3(0.131 \mathrm{~g}, 0.402 \mathrm{mmol})$ in dry THF $(0.50 \mathrm{~mL})$ dropwise over ca. $40 \mathrm{~min}$ (when reddish color of the reaction mixture disappeared, the 
next drop of the solution was added) at $0{ }^{\circ} \mathrm{C}$ with stirring. The reaction mixture was stirred at $0{ }^{\circ} \mathrm{C}$ for $22 \mathrm{~h}$, quenched with saturated $\mathrm{NH}_{4} \mathrm{Cl}$, and extracted with $\mathrm{CH}_{2} \mathrm{Cl}_{2}$. The organic layer was dried over $\mathrm{MgSO}_{4}$ and evaporated. The residue was purified by preparative HPLC (eluent: $\mathrm{CHCl}_{3}$ ) using polystyrene gel column to give poly3 as a viscous off-white solid (10\%): ${ }^{1} \mathrm{H}$ NMR $\left(500 \mathrm{MHz}, \mathrm{CDCl}_{3}\right) \delta 7.43-7.10(\mathrm{~m}, 1 \mathrm{H})$, 6.95-6.47 (m, 3 H), 3.73-3.43 (m, $11 \mathrm{H}), 3.34-3.33$ (m, $3 \mathrm{H}), 1.19-0.97$ (m, $3 \mathrm{H})$; IR (KBr) 2969, 2875, 1648, 1103, $755 \mathrm{~cm}^{-1}$.

Poly4. Viscous light brown solid (44\%): ${ }^{1} \mathrm{H}$ NMR (500 MHz, $\left.\mathrm{CDCl}_{3}\right) \delta 7.50-7.18(\mathrm{~m}$, $1 \mathrm{H}), 7.00-6.38$ (m, $3 \mathrm{H}), 3.99-3.43$ (m, $15 \mathrm{H}), 3.39-3.35$ (m, $3 \mathrm{H}), 1.18-0.93$ (m, $3 \mathrm{H})$; IR (KBr) 2965, 2928, 2874, 1648, 1107, $754 \mathrm{~cm}^{-1}$.
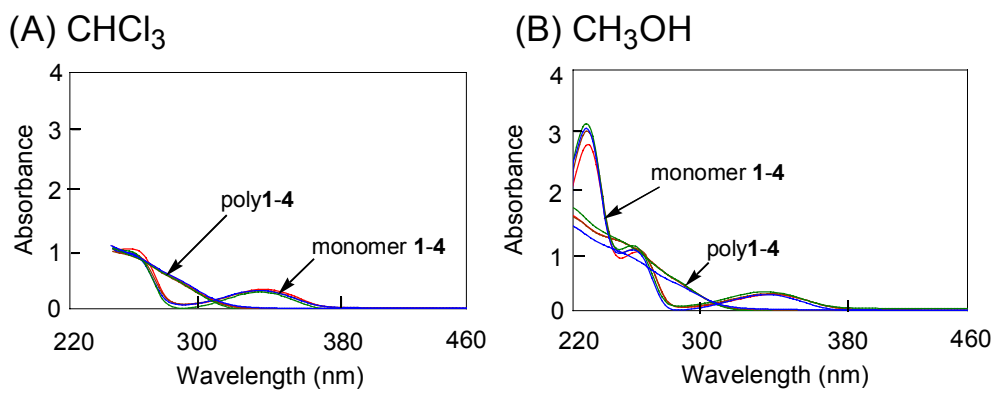

(C) $\mathrm{H}_{2} \mathrm{O}$

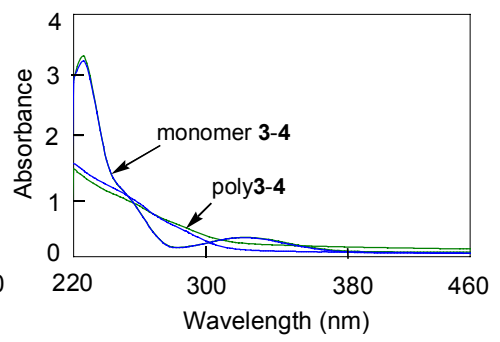

Figure S1. UV spectra of 1 and poly1 (red line), 2 and poly 2 (brown line), 3 and poly3 (green line), and 4 and poly4 (blue line) in (A) $\mathrm{CHCl}_{3}$, (B) $\mathrm{CH}_{3} \mathrm{OH}$, and $(\mathrm{C}) \mathrm{H}_{2} \mathrm{O}$.

(A)

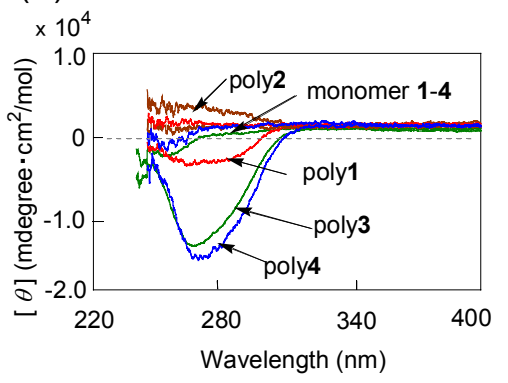

(B)

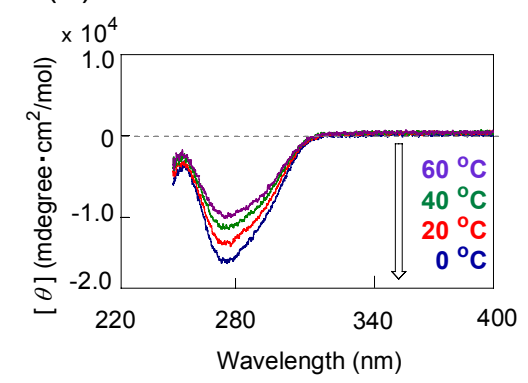

Figure S2. (A) CD spectra of 1 and poly 1 (red line), 2 and poly 2 (brown line), $\mathbf{3}$ and poly3 (green line), and 4 and poly4 (blue line) in $\mathrm{CHCl}_{3}$ at $25^{\circ} \mathrm{C}$. (B) $\mathrm{CD}$ spectra of poly4 in $\mathrm{CHCl}_{3}$ at $0{ }^{\circ} \mathrm{C}$ (blue line), $20{ }^{\circ} \mathrm{C}$ (red line), $40{ }^{\circ} \mathrm{C}$ (green line), and $60{ }^{\circ} \mathrm{C}$ (violet line). The $\mathrm{CD}$ study in $\mathrm{CHCl}_{3}$ was limited due to the absorption of $\mathrm{CHCl}_{3}$ below $250 \mathrm{~nm}$. 

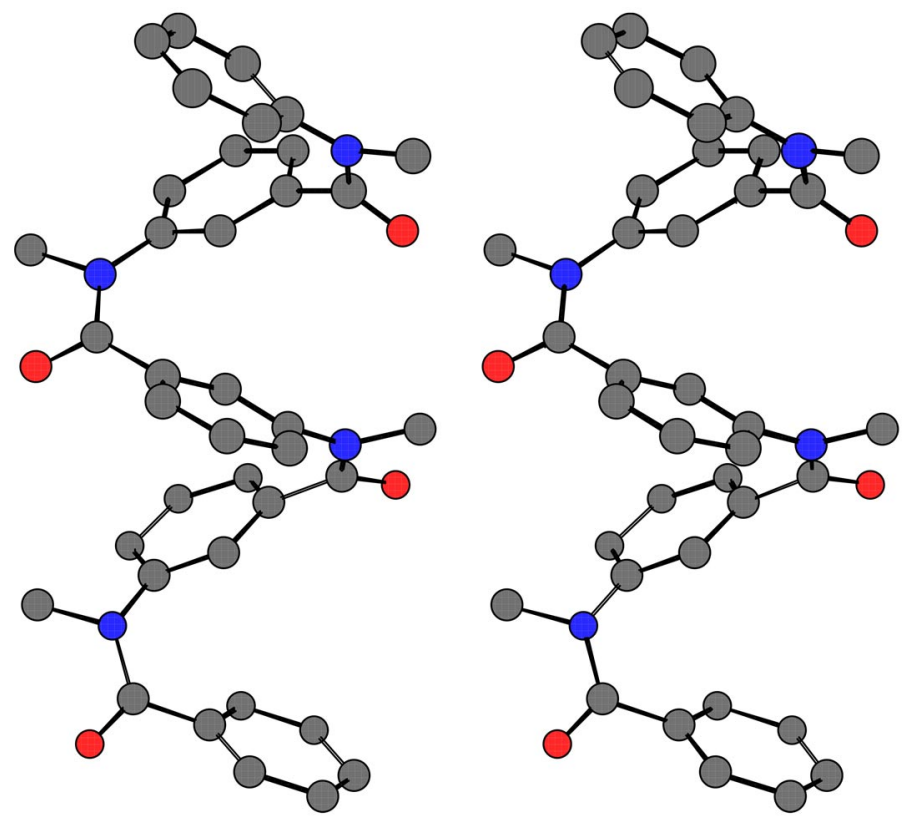

Figure S3. Stereoview of the proposed helical conformation of 3-(methylamino)benzoic acid pentamer with the anti arrangement. Hydrogen atoms and terminal amino and carbonyl groups are omitted for clarity.
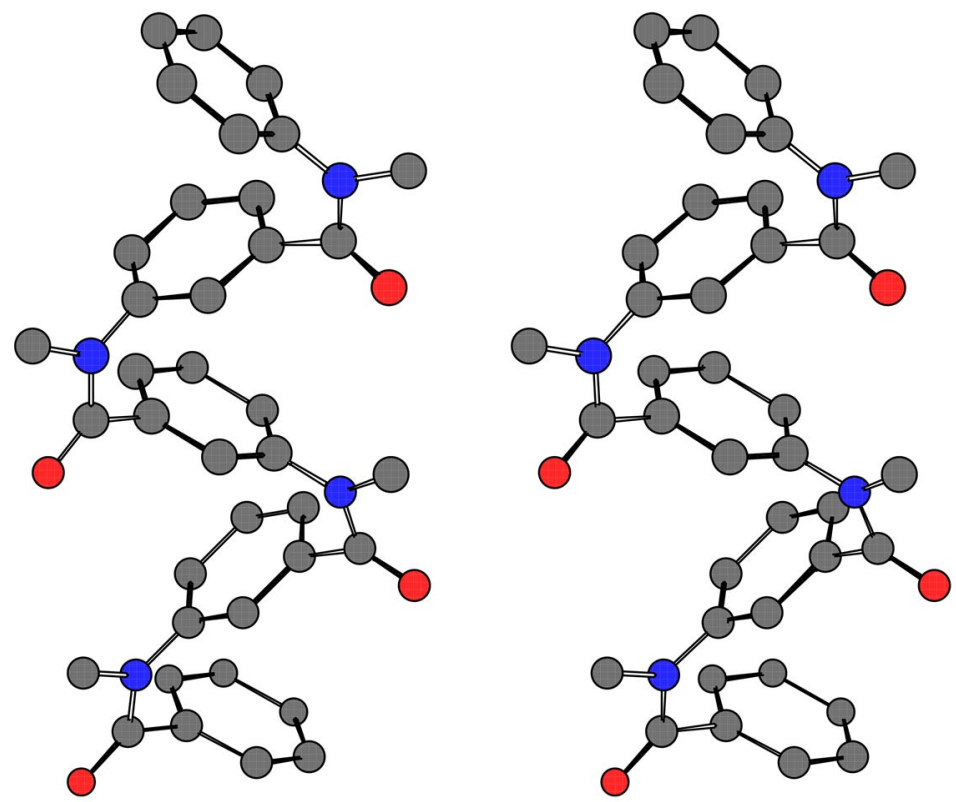

Figure S4. Stereoview of the proposed zigzag conformation of 3-(methylamino)benzoic acid pentamer with the anti arrangement. Hydrogen atoms and terminal amino and carbonyl groups are omitted for clarity. 

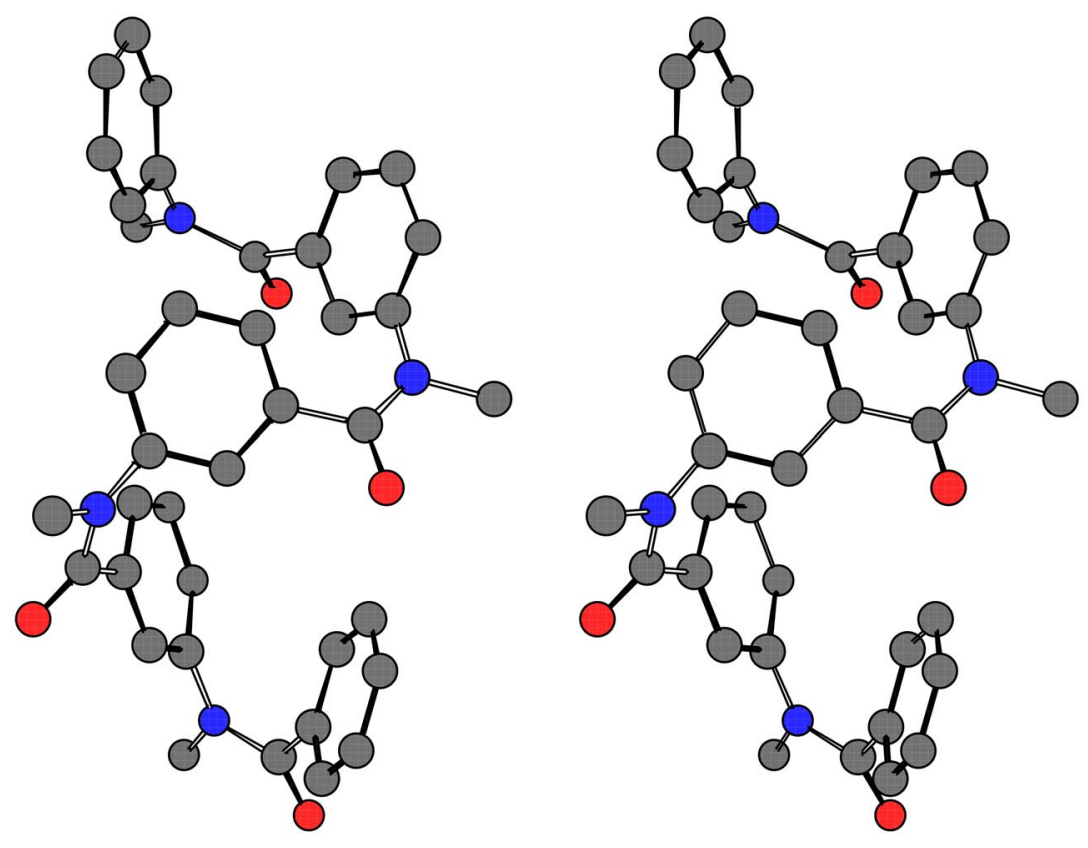

Figure S5. Stereoview of the proposed helical conformation of 3-(methylamino)benzoic acid pentamer with the syn arrangement. Hydrogen atoms and terminal amino and carbonyl groups are omitted for clarity.

\section{REFERENCES}

(1) Brunner, H.; Wachter, J.; Schmidbauer, J.; Sheldrick, G. M.; Jones, P. G. Organometallics 1986, 5, 2212-2219.

(2) Reichardt, C.; Budnik, U. Chem. Ber. 1990, 123, 2023-2030.

(3) Abdel-Magid, A. F.; Carson, K. G.; Harris, B. D.; Maryanoff, C. A.; Shah, R. D. J. Org. Chem. 1996, 61, 3849-3862.

(4) Prince, R. B.; Brunsveld, L.; Meijer, E. W.; Moore, J. S. Angew. Chem., Int. Ed. 2000, 39, 228-230. 